Meta

Journal des traducteurs

Translators' Journal

\title{
Functional Sentence Perspective in Seven Translations of Anna Karenina
}

\section{Ljubov A. Prozorova}

Volume 37, numéro 1, mars 1992

La traduction en Russie : théorie et pratique / Translation in Russia: Theory and Practice

URI : https://id.erudit.org/iderudit/003876ar

DOI : https://doi.org/10.7202/003876ar

Aller au sommaire du numéro

Éditeur(s)

Les Presses de l'Université de Montréal

ISSN

0026-0452 (imprimé)

1492-1421 (numérique)

Découvrir la revue

Citer cet article

Prozorova, L. A. (1992). Functional Sentence Perspective in Seven Translations of Anna Karenina. Meta, 37(1), 127-138. https://doi.org/10.7202/003876ar
Résumé de l'article

On précise les notions utilisées traditionnellement pour représenter l'ordre des idées dans une phrase ; on étudie ensuite les mécanismes concernés et la manière dont leur analyse permet l'évaluation de l'adéquation d'une traduction. 


\title{
FUNCTIONAL SENTENCE PERSPECTIVE IN SEVEN TRANSLATIONS OF ANNA KARENINA
}

\author{
Ljubov A. Prozorova \\ Moscow Linguistic University,
} MOSCOw, USSR

\section{Résumé}

On précise les notions utilisées traditionnellement pour représenter l'ordre des idées dans une phrase; on étudie ensuite les mécanismes concernés et la manière dont leur analyse permet l'évaluation de l'adéquation d'une traduction.

For more than a century now linguists have been conscious of the fact that there is no one-to-one correspondence between the order of words and "the order of ideas" in a sentence. Even as far back as $1869 \mathrm{H}$. Weil noted that the study of the correlation between these two orders may give us a clue to the working of different languages and may therefore be effectively used in typological and contrastive linguistics.

V. Mathesius (see e.g. 1967), a Prague linguist, gave the "order of ideas" the name of functional sentence perspective (FSP) and called the idea that comes first in the semantic structure of a sentence the starting point (also known as theme or topic, what the sentence is about) and the idea that follows it the nucleus (rheme, comment, focus, what is said about the theme). Since that time the study of FSP has been a constant movement towards more precision: sexpartition was introduced instead of bipartition (see e.g. Firbas 1964; Bily 1981; Szwedek 1985), the given-new opposition was distinguished as a phenomenon separate from the theme-rheme opposition (Halliday 1967), some aspects of the correlation between logical stress and FSP were shown (Nikolaeva 1982), etc.

However, as matters stand now, FSP has not yet received a unified definition. There are still some doubts concerning the character of the relation binding communicative elements (CEs) within the semantic structure of a sentence (calling these CEs themes and rhemes or otherwise is just a matter of terminology). The general attitude to FSP was well worded by A. Szwedek (1989: 499): "it seems that a more scrupulous analysis would be advisable to give the concept full legitimacy, or to show its uselessness."

Since the attempts to substitute FSP analysis by the analysis of presuppositions (e.g. Jackendoff 1972), relevance (Sperber and Wilson 1986), etc. do not seem a convincing enough proof that we can do without FSP, in the present paper we shall try to give more precision to the notions traditionally used to describe FSP, get an insight into its mechanism and show how the analysis of this mechanism can be used to assess the adequacy of translation.

The basic notion behind the view of FSP taken here (in the main it coincides with the one suggested by Seliverstova 1984) is that the communicative structure of a sentence is made up of a number of CEs (they can coincide with sentence elements or with more complex syntactic units) connected by vector relations of characterization. The essence of these relations is that some of the CEs attribute certain characteristics to other CEs 
(cf. Benes 1968; Bolinger 1975: 100). CEs may form clusters (CEs of higher ranges) and finally the sentence may be split into two major clusters (the main object of characterization, topic, and the rest of the sentence, comment). Thus, roughly, saying John is sitting there (the arrow shows the vector relation from comment to topic), we attribute to John (topic) the characteristic of being the agent of the action of sitting (comment). Conversely, saying Sitting there is John we attribute to the action of sitting (topic) an agent: John (comment). In the latter case we can speak of an action oriented (vS subject oriented) sentence.

If a sentence does not fall into two parts there may be different configurations on the top level. An important point is that all the relations are supposed to be of the same kind, though sometimes of different ranges. M. Noonan's (1976) example could be then presented as follows: Ol'George Creech, his son just wrecked his new Chevy, where Ol' George Creech is characterized through what his son did to his car and his son is characterized through what he did to the car. Since the order of CEs does not always coincide with the order of words, the positions of different CEs are determined through tests.

Previously tests were given by the author (see e.g. Prozorova 1990) bearing out Noonan's (1976) hypothesis that in sentences like A man came into the room, A man came up to him a man can at least very often be topic (the main object of characterization). This throws some light on the functioning of such sentences in the text (see e.g. Seliverstova, Prozorova 1990; Prozorova, Seliverstova 1990). The translation of these tests into Russian shows that in Russian sentences of the same type FSP is the same and consequently one should try, if possible, to preserve the sentence structure in translation or to use some compensatory means if the structure has to be changed due to some constraints.

As sentences of the type mentioned above will be discussed further, let us look at some of the tests. When we say that B is a characteristic of A it should be possible to test whether it is so. For instance we can find cases where B cannot characterize A or B is an inappropriate characteristic of $A$ in the given situation. If a sentence with such $B$ remains regular, then $B$ is not a characteristic of $A$. If the sentence becomes absurd or otherwise incorrect, then B is a characteristic of A. As a particular instance of this we can find a situation where a person cannot be within a certain place: a girl cannot be inside a lock, a waiter cannot be inside a sink, etc.

In sentences like $A$ man came into the room the verb normally shows the relation between the agent and the place. Thus, saying $A$ boy hid in the chest we mean that the boy is within the chest. If we say A girl threw a stone into the well the girl is most likely to be outside the well.

But under some conditions (like the presence of an object and a certain type of verb and preposition) the locative can be doubly interpreted as containing the agent and the event or as containing only the event.

In such dubious cases the positional difference proves to be decisive in establishing the true relation. If we put the locative first In the room Mary was watering the flowers the place is perceived as containing the agent i.e. Mary is taken to be inside the room. When in actual reality the place cannot contain the agent the sentence becomes absurd. Cf::

(1) - In the lock a girl was ineffectually turning a key.

- В замке какая-то девочка безуспешно вертела ключ.

(2) In the fish-bowl a boy was feeding fish.

- В аквариуме какой-то мальчик кормил рыбок. 
(3) - In the sink a waiter was trying to kill a cock-roach.

- В раковине какой-то оФциант пытался поймать таракана. ${ }^{1}$

This can be explained by the fact that the locative in such sentences is topic, to which the rest of the sentence attributes certain characteristics. Thus the agent is also perceived as one of the characteristics of the place and consequently can be seen as being within the place.

Now let us consider sentences where the locative (given) is placed at the end of the sentence and the agent (new) comes first. If the locative in these sentences was topic they would still remain awkward when the place cannot be seen as containing the agent. But in actual fact these sentences are all right. $\mathrm{Cf}$.:

(4) We stole past the entrance to our neighbour's flat. A girl was ineffectually turning a key in the lock.

Мы осторожно прокрались мимо двери наших соседей. Какая-мо девочка безуспешно вертела ключ в замке.

(5) I could see that this was a family that loved pets. A boy was feeding fish in the fishbowl. я сразу увидел, что в этом доме любят животных. Какой-то мальчик кормил рыбок в аквариуме.

(6) I could see that the restaurant's kitchen was hardly hygienic. The first thing that caught my eye was a dirty sink. A waiter was trying to kill a cock-roach in it. было заметно, что кухня в этом ресторане не очень-то чистая. Первое, что попалось мне на глаза - это грязная раковина. Какой-то офиц̆иант пытался поц̆мать в нец̆ таракана.

This proves that the locative in such sentences functions as the comment, the topic being the agent (new).

Another test is conjunction where another predicate and another locative is added. It is as follows. If in sentences like Raindrops drummed on the metal roof the locative was topic, it would not be possible to expand them adding another predicate and a different locative for then one place would be characterized by what is happening in another place. In actual fact we can very well expand such sentences which shows that topic in them is the agent and not the locative. Cf.:

(7) Raindrops drummed on the metal roof and spattered the leaves of the cherry-tree. Капли дождя стучали по железной крыше, бриллиантовой росой блестели на листьях старой вишни.

(8) Yellow leaves fluttered on the gnarled branches of the tree and dappled the paths in the garden.

Желтые листья трепетали на корявых ветвях дерева, яркими пятнами лежали на дорожках сада.

(9) Ancient roots sank deep down into the ground and sprang up to break the forest path. Столетние корни глубоко уходили в землю, узловатой сеткой покрывали лесную тропу.

Cf. these with (10-12) where the locative stands in the clearly thematic initial position. We cannot expand these:

(10) - On the metal roof drummed raindrops and spattered the leaves of the cherry-tree. - По железной крыше стучали капли дождя, бриллиантовой росой блестели на листьях старой вишни.

(11) - On the gnarled branches of the tree fluttered yellow leaves and dappled the paths in the garden.

- На корявых ветвях дерева трепетали желтые листья, яркими пятнами лежали на дорожках сада. 
(12) Deep down into the ground sank ancient roots and sprang up to break the forest path. - Глубоко в землю уходили столетние корни, узловатой сеткой покрывали лесню тропу.

Here is another proof that in sentences like $A$ man came into the room the agent (new) functions as topic. Comment, attributing a characteristic to topic, excludes all the other characteristics, so the main function of comment is contrastive. The pronoun someone can hardly be contrasted to anything, unlike nouns. Cf.: This is an oak (and not a birch) and This is someone (and not:...) So the pronoun someone cannot be placed alone into the rhematic position:

(13) - Under the table sat someone.

- Под столом сидел кто-то.

If in sentences with the agent (new) in the initial position the agent was also comment, someone would not be possible as the agent. But facts testify to the contrary:

(14) Someone sat under the table. Кто-то сидел под столом.

is a regular sentence. This proves that the agent (new) in such sentences is topic, quod erat demonstrandum.

Earlier (Prozorova 1989) a number of tests and facts were given proving Seliverstova's (1984) hypothesis that being internally oriented a sentence may at the same time be externally oriented or global, according to Nikolaeva (1982). Cf.: What's this dreadful noise? Father is playing the violin. The sentence Father is playing the violin as a whole answers the question; at the same time Father is characterized as the agent of the action of coming. Being oriented towards the agent (new) sentences like $A$ man entered the room can at the same time function as a complex comment (or rheme) of a higher range related to a preceding comment (given or implied), i.e. they are externally oriented (global).

(15) "Now, now, now, now! What's this, what's this?" A thin crackly little voice came form the back of the shop. (P.L. Travers, Mary Poppins.)

If we change the word order, placing the locative first:

(16) From the back of the shop came a thin crackly little voice,

- the impression that the person who spoke the words is identical with the "owner" of the thin crackly little voice will be lost. This happens because the sentence following the direct speech loses external orientation and consequently is no longer perceived as characterizing the previous context. Cf. the same in Russian:

(17) - Ну-ну-ну! Что такое, что такое? Тоненький, писклявый, надтреснутый голосок послышался из глубины лавки.

and in the same context: ? Из глубины лавки послышался тоненький, писклявый, надтреснутый голосок.

Numerous examples from fiction (see Prozorova, Seliverstova 1990) demonstrate that some of the so-called "topicless" sentences (Grzegorek 1984) in fact have both an external and an internal topic and may be chosen in the text for two basic reasons: either for their globality or for the sake of choosing a new topic rather than a given one.

On closer examination it turns out that the effect of the choice of a new topic can be different depending on the characteristics of the text or part of text in which the sentence is used. According to these characteristics different types of texts can be distinguished. 
Now let us look at Anna Karenina by Lev Tolstoy and see how sentences with the new topic in the initial position function in it under different circumstances and how they can be best translated into English.

The first type of texts to be considered presents a single situation, localized in time and space (e.g. here and now). At least one given character is present on the scene, who is deep in thought or whose attention is firmly focused on something vital for him. Then a new character appears or is noticed in the vicinity of the given character. In this situation theoretically there are equal chances in Russian that either the given or the new character will be chosen as topic, e.g. we can say either E§o обо\$нал какоц̆-мо мальчцк (He was overtaken by a boy) or Какоц̆ то мальчцк обњнал еङо (A boy overtook him). It was previously shown (Prozorova, Seliverstova 1990) that the choice of one or the other FSP partly depends on the character of the situation (the less the actual impact the actions of the new character have on the given main character, the more natural it is not to choose the main character as theme) and partly on the stylistic effect which the author intends to achieve.

If the given character is chosen as topic the effect is that the presence of the actions of the new person characterize him in some way. Cf. an example suggested by O. Seliverstova (Prozorova, Seliverstova 1990):

(18) Она медленно шла по дороге. Ее обогнал какоц̆-мо офицер, затем старая женщина.

She was slowly walking down the road: She was overtaken by some young officer, then by an old woman.

In (18) we are told about people overtaking her, which allows us to consider the whole event as related to her. The fact that she is characterized through people overtaking her emphasizes the impression that she walked slowly.

When a new topic is chosen the impression is created that the new character is connected with the main character only through being in the same setting with him. This new character can be seen as part of the background or as the centre of an independent episode (which may later be "woven" into the main line). Cf. an episode from Anna Karenina where Levin is hurrying to the skating-rink in the hope of seeing Kitty there. $\mathrm{He}$ is in love with the girl and he longs to meet her as soon as possible, so he hardly notices anything around:

(19) Он шел по дорожке к катку и говорил себе: "Надо не волновать-ся, надо успокоиться. О чем ты? Чего ты? Молчи, глупое," - обращался он к своему сердцу. И чем больше он старался себя успокоить, тем все хуже захватывало ему дыхание. Знакомый встретился и окликнул его, но Левдн даже не узнал, кто это был. Он подошел к горам... (Tolstoy 1960: 35)

In the given episode (19) the main stress is laid on presenting everything and everyone but Kitty as irrelevant, unconnected with Levin. Hence the choice of the new person appearing, the acquaintance, as an independent topic rather than as an element characterizing Levin. ${ }^{2}$

Let us see how this episode is translated into English by Constance Garnett:

(19a) He walked along the path towards the skating ground, and kept saying to himself "You mustn't be excited, you must be calm. What's the matter with you? What do you want? Be quiet, stupid," he conjured his heart. And the more he tried to compose himself, the more breathless he found himself. An acquaintance met him and called him by name, but Levin did not even recognize him. He went towards the mounds... (Gamett 1917, vol. 1: 37) 
As we can see the FSP of the italicized sentence in the original is preserved in the translation, so is the stylistic effect. In five of the other translations analyzed the new topic is also chosen, which is the most natural thing to do in English in the case. However, in the translation by Louise and Aylmer Maude FSP is different. Cf.:

(19b) He met an acquaintance who called to him, but Levin did not even notice who it was. (Maude 1933, Vol. I: 31.)

(19b) is hardly acceptable as an adequate translation because the fact that Levin is chosen as topic here makes us see his thoughts about Kitty and his meeting an acquaintance as information of comparable value related to him. This destroys the stylistic effect created in the original. Cf. a similar episode where the attention of the main character, Levin, is focused on another character, Kitty, and all the people around are seen only as part of the background.

(20) Она была на угле и, тупо поставив узкие ножки в высоких ботинках, видимо робея, катилась к нему. Отчаянно махавший руками и прцгибавшийся к земле мальчик в русском платье обгонял ее. Она катилась не совсем твердо; вынув руки из маленькой муФты, висевшей на снурке, она держала их наготове и, глядя на Левина, которого она узнала, улыбалась ему и своему страху. (Tolstoy 1960: 36)

No further mention of the boy is made. He is merely seen as entering Levin's field of vision and vanishing without leaving any trace. There is no impression that he is connected with Kitty or characterizes her in any way. The boy is seen as the centre of an independent background episode. Cf. the translations:

(20a) She was in a corner, and turning out her slender feet in their high boots with obvious timidity, she skated towards him. A boy in Russian dress, desperately waving his arms and bowed down to the ground, overtook her. She skated a little uncertainly; taking her hands out of the little muff, that hung on a cord, she held them ready for emergency, and looking towards Levin, whom she had recognized, she smiled at him and at her own fears. (Garnett 1917, vol. I: 38.)

There are two translations in which the presentation differs noticeably from (20a):

(20b) She, evidently not quite at ease on her high skates, glided towards him from the place where she had been standing, followed by a young man in Russian costume, who was trying to get ahead of her, and making the desperate gestures of an unskilful skater. Kitty herself did not skate with much confidence. (Dole 1886: 35)

In (20b) the fact that the new character is introduced in a participial construction characterizing Kitty's actions creates the effect that these two people are connected with each other, that the fact of her being followed by the boy adds something to her image. Cf. Kitty came down the stairs followed by several young men, where the fact that she was being followed by several young men may characterize her as the object of attention on the part of men. The word trying might create the impression that there was a competition between Kitty and the boy which would not be relevant in the given context. Also, the words Kitty herself show that Kitty and the boy are being compared. This presentation differs radically from the one given by Tolstoy, who used every means to show that for Levin no one existed but Kitty who is metaphorically identified with the sun in the sentence preceding the extract analyzed (20).

In another translation, by Joel Carmichael, the FSP of the original is preserved, but the choice of words is at cross purposes with FSP:

(20c) A little boy in Russian costume, violently waving his arms and stooping down very low, was catching up with her. (Carmichael 1960: 30) 
The words catching up in (20c) suggest that Levin, through whose eyes we see the episode, saw this action as purposeful and in some way connected with Kitty (it was the boy's intention to reach her). The FSP and the choice of words in the original create no such impression. The best translation is perhaps the one given by Rosemary Edmonds:

(20d) A small boy in Russian dress, desperately waving his arms and stooping very low, was overtaking her. (Edmonds 1962: 42)

Another type of text is different from the one described only in that the new person appearing manages to interrupt the main character's reverie or otherwise attract his attention. In this case the effect of an intrusion is created if the new character is chosen as topic. Cf. an episode where Anna Karenina is lost in thought contemplating a possible suicide.

(21) С остановившеюся улыбкой сострадания к себе она сидела на кресле, снимая и надевая кольца с левой руки, живо с разных сторон представляя себе его чувства после ее смерти.

Приближающиеся его шагц, развлекли еe. (Tolstoy 1960: 820)

Translating texts of this type where the effect of intrusion is obvious all the translators show unanimity in preserving the FSP of the original. Cf. e.g.:

(21a) With the trace of a smile of commiseration for herself she sat down in the armchair, taking off and putting on the rings on her left hand, vividly picturing from different sides his feelings after her death.

Approaching footsteps - his step - distracted her attention. (Garnett 1917, Vol. II: 401)

(21b) Sounds of approaching steps, his steps, distracted her thoughts. (Maude 1933, Vol. II: 353)

(21c) Approaching steps — his steps - caught her ears. (Dole 1886: 701)

Most difficult for translation are Russian sentences with a predicate (in the wider sense of the part of the sentence denoting an event - vs.e.g. place) in the initial position, which often have no direct equivalents in English. Cf.: Нцчељо веселољо ц рабостнољо не было в этом чувстве (Lit.: Nothing cheerful or joyous was in this feeling). The interpretation of these sentences as predicate oriented and global is a hypothesis (Seliverstova 1984: 454) which still has to be tested. Only one test has been suggested by the author so far proving the global character of these sentences (see Seliverstova, Prozorova 1990). This test is based on the assumption that in a global sentence a given comment cannot be put into a syntagmatically contrastive position because the whole situation described in a sentence attributes a characteristic to an external topic and therefore is contrasted as a whole with another situation or event (in the wider sense of the word). Cf.:

(22) Who is singing? - Mary is singing (and not dancing).

Russian sentences with predicates in the initial position fall under this rule. E.g. we can hardly say something like (23):

(23) ?Красивый парень Петр, а Павел - некрасивый.

Lit.: A handsome fellow is Peter but Paul is not handsome. 
(23) would be possible only if Peter is new. This proves that the sentence Красцвыц парень Петр as a whole takes part in the comparison. Thus one cannot use a sentence like (24) in isolation, when the speakers suddenly started talking about Peter and Paul.

(24) Красивый парень Петр, но Павел еще красивее. Lit.: A handsome fellow is Peter, but Paul is more handsome.

A sentence like (24) can be used only in a situation when some actions, judgements or events are given prior to this sentence and the latter provides a cause of the preceding events. Cf:

(25) И вышла Дуняша замуж не эа Петра, а за Павла. Да оно и не удивительно красивый парень Петр, но Павел еше красивее.

Lit.: And married Dun'asha not Peter but Paul. And this is not at all surprising: a handsome fellow is Peter, but Paul is more handsome.

From this we can draw the conclusion that it is not Peter and Paul that are being compared from the point of view of their characteristics, but the beauty of Peter and the beauty of Paul in respect to the previously introduced situation.

The use of sentences with predicates in the initial position in Anna Karenina also bears out their global character. They are used for instance in the following type of texts. It resembles the first two types described above in that it presents a single situation located in time and space (i.e., not a generalization) and at least one of the main characters is present on the scene. Then comes a sentence telling us that something or someone else is present on or is absent from the scene. In this situation there is also a double possibility of arranging the sentence. Cf.:

(26) Никого не было в церкви.

Lit.: No one was in the church

(27) В церкви никого не было.

Lit.: In the church was no one.

The presentation in the two cases is different. When we choose a global sentence like (26) the sentence characterizes the previous situation. It can show that the emptiness of the church agrees with or contradicts the character's state of mind, or that the absence of people somehow helps him or prevents him from achieving his purpose. Tolstoy's choice bears out this interpretation. In all the cases where event oriented global sentences are used the situation presupposes that what the character finds on the scene immediately concerns his previous actions or state of mind. Cf. an episode (28) where Levin does not want his visitors to go to a marsh and hunt there because he was saving that marsh for himself. Still they go there and Levin is enviously looking on in the hope that they will not find anything.

(28) Левин остался у линейки и с завистью смотрел на охотников. Охотники прошли все болотце. Кроме курочки и чибисов, из которых одного убил Васенька, ничего не было в болоте - Ну вот видите, что я не жалел болота, сказал Левин, - только время терять.

Here the global clause ничего не было в болоте (Lit.: nothing was in the marsh) due to its external orientation emphasizes the impression that the absence of fowl in the marsh has an immediate connection with the previous situation: i.e., in this case it corresponds to Levin's expectations. The description of English sentences like No one was at the station given by O. Seliverstova is similar to our description of (26) so sentences of this type would be an ideal translation in such cases if there are no 
restrictions on their use. As for the seven translations analyzed, Constance Garnett's seems to be the closest translation as far as the effect discussed is concerned. Cf.:

(28a) Levin remained with the wagonette, and looked enviously at the sportsmen. They walked right across the marsh. Except little birds and peewits, of which Vassenka killed one, there was nothing in the marsh.

"Come, you see now that it was not that I grudged the marsh," said Levin, "only it's wasting time." (Garnett 1917, vol, II: 187)

(28b) ... Levin stood behind to watch the horses. Veslovsky killed a moor-hen and a lapwing, which was all they found, and Levin felt somewhat consoled. (Dole 1986: 568)

Dole's translation (28b) obviously goes against the grain of the original, as it presents Veslovsky's actions as the centre of Levin's attention, whereas in the original Levin is supposed to be concerned mainly with the marsh fowl being undisturbed. Garnett's presentation (with some reservations as far as the choice of words goes) is closer to the original, for the part italicized due to its globality can be shown as having an immediate impact on Levin's feelings. The translations by Maude, Carmichael and Edmonds have the same structure making Levin's visitors the topic of complex sentence and creating an effect that the absence of fowl in the marsh concerns more the visitors than Levin himself. Cf. e.g.:

(28c) They went over the whole marsh, but there was nothing in it but some waterfowl and peewits, one of which was shot by Veslovsky. (Carmichael 1980: 619)

A similar thing happens in the translations by Margaret Wettlin and Rochelle Townsend where the information about the absence of fowl in the marsh is tied directly to Levin's visitors (they found nothing) and there is no indication that this immediately concerned Levin. Cf. (28d) and (28e):

(28d) They covered the entire marsh. Except for pewees of which Veslovsky brought down one, they found nothing in this marsh. (Wettlin 1982, vol. II: 192)

(28e) They found nothing but a wild hen and some plovers, of which Vasenka killed one. (Townsend 1960, vol. II: 138)

As we can see most of the translations in this case are wide of the mark. This testifies to the fact that there is no intuitive understanding of the nature and effect of FSP in the Russian structure described under the given conditions. On the other hand, when feelings are concerned (e.g. the absence or presence of feelings in the character's soul) the effect of the tropicalization of the "predicate" is very clearly seen by the translators for there is, in most cases, a direct correspondence between the English and Russian structures including words which signify emotions. Cf. e.g. the way Tolstoy describes the feelings experienced by Levin when his son was born:

(29) Что он испытывал к этому маленькому существу, было совсем не то, что он ожидал. Ничего веселого и радостного не было в этом чувстве; напротив, это был новый мучительный страх. Это было сознание новой области уязвимости. (Tolstoy 1960: 791)

The text shows the contrast between Levin's expectations and what he really felt for the boy, so the choice of the global sentence here is natural. All the translators chose a global structure in English with the construction "there is." Cf. e.g.:

(29a) What he felt towards this little creature was utterly unlike what he had expected. There was nothing cheerful and joyous in the feeling; on the contrary, it was a new torture of apprehension. It was the consciousness of a new sphere of liability to pain. (Garnett 1917, vol. II: 368) 
(29b) ... There was nothing merry or joyful in it; on the contrary, there was a new and distressing sense of fear. (Maude 1933, vol. II: 324)

$(29 \mathrm{c})$ There was nothing merry or joyous in his feeling; on the contrary there was a new and painful fear - the consciousness of a new area of vulnerability. (Carmichael 1960: 765)

When a locative oriented sentence (see Bolinger 1975: 100-102) like (27) is chosen in the type of texts analyzed, there is no external orientation and only the place is characterized from the point of view of what was present in or absent from it. Usually such sentences are chosen when the main character is not concerned about what is happening before his eyes, his thoughts are wandering elsewhere and he merely notes impassively what he sees without getting emotionally involved. The use of such sentences by Tolstoy in the type of text in question bears out this interpretation. Cf. an episode (30) where Vronsky comes to the theatre after Anna had already gone there. He is anticipating a scandal for it was not considered proper for her to appear in public after she had left her husband for a lover. Vronsky barely notices what is happening around him for all his powers are collected to meet the impending blow.

(30) Вронский вошел в театр в половине девятого. Спектакль был во всем разгаре. Капельдинер - старичок снял шубу с Вронского и, узнав его, назвал "ваше сиятельство" и предложил ему не брать нумерка, а просто крикнуть Федора. В светлом коридоре никого не было, кроме капельдинера и двух лакеев с шубами в руках, слушавших у двери. (Tolstoy 1960: 601)

Four out of the seven translations have locative or subject oriented sentences in place of the sentence italicized, thus creating an effect similar to the one of the original. Cf. e.g.:

(30a) Vronsky went into the theatre at half-past eight. The performance was in full swing. The little old box-keeper, recognizing Vronsky as he helped him off with his fur coat, called him "Your Excellency," and suggested he should not take a number but should simply call Fyodor. In the brightly lighted corridor there was no one but the boxopener and two attendants with fur cloaks on their arms listening at the doors. (Garnett 1917, vol. II: 145-146)

(30b) ... The brilliantly lighted corridor was empty save for the box-attendant and two footmen with fur cloaks over their arms listening at the doors. (Edmonds 1962: 574)

However, the translations by Maude, Carmichael and Wettlin present (30) in a way indistinguishable in effect from (28) or (29). Cf. e.g.:

(30c) ... There was no one in the brightly-lighted foyer but this old man and two footmen with fur cloaks in their arms listening at a chink in the door. (Wettling 1982, vol. II: 147)

It is significant that in the translation of a similar episode (31) only two translators preserved the FSP of the original, one of them being Wettlin who failed to do so in (30). In (31) we learn that Levin decides to confess before his wedding. He is not a religious man and going to church is just a tiring but necessary routine for him. His thoughts are not about the prayers and the confession. He is thinking of Kitty and of his landowner's duties and idly notes what is going on around, eager to go through with it and be free.

(31) Он отстоял обедню, всенощную и вечерние правила и на другой день, встав раньше обыкновенного, не пив чаю, пришел в восемь часов утра в церковь для слушания утренних правил и исповеди.

В церкви никого не было, кроме нищего солдата, двух старушек и церковнослужтелей. 
Молодой дьякон... встретил его и тот час же... стал читать правила. (Tolstoy 1960: 484)

Most of the translations make the effect of the original less obvious by introducing a global sentence with the construction "there is." Cf. e.g.:

(31a) He had stood through the litany, the evening service and the midnight service, and the next day he got up earlier than usual, and without having tea he went at eight o'clock in the morning to the church for the morning service and the confession.

There was no one in the church but a beggar soldier, two old women, and the church officials.

A young deacon... met him and at once... read the exhortation. (Garnett 1917, vol. II: 7-8)

The Maude translation is even further away from the original for in it a predicate oriented sentence identical in effect with the Russian ones in (28) and (29) is used to tell us there were no people in the church.

(31b) ... No one else was in the church except a soldier-beggar, two old women, and the clergy. (Maude 1933, vol. II: 3)

The two translations where the stylistic effect of the locative oriented sentence of the original is preserved substitute this sentence by the one where the church becomes both subject and topic. Cf.:

(31c) ... The church was deserted; he saw nobody except a mendicant soldier, two old women, and the officiating priests. (Dole 1886: 446)

(31d) ... The church was empty except for a poor soldier, two old women and a few celebrants. (Wettlin 1982, vol. II: 11)

(31c) is not so good as (31d) for in the second part of the sentence in (31c) Levin creeps in as topic whereas in the original everything is presented as happening on its own without Levin's participation: people are praying, the deacon is performing his rites, etc.

The analysis of the examples (28-31) and their translations shows that whereas there is an obvious distinction between predicate oriented (28-29) vs. locative or subject oriented sentences (30-31) in Russian, this distinction is not intuitively felt by English translators except, perhaps, for the cases where words denoting emotions are involved. With this in view one may need a linguistic explanation for such or similar usages.

In conclusion it is possible to say the FSP is a powerful style-building instrument and by ignoring it a translator may drift very far away from the original. It seems an important point that the stylistic effect produced by the use of a sentence with a certain FSP may depend on the characteristics of a text or part of text in which it is used. The present article was written in the hope that the analysis presented here will be a convincing enough proof that provided it is given more precision FSP study can be effectively used to assess the adequacy of translation and that FSP analysis can successfully guide a translator through the most tangled debris of text structure.

Notes

1. In case of a syntagmatic contrast (with the agent given) the locative obviously performs a different function which accounts for a different perception. Cf.: In the sink Peter washed the socks and in the bath he washed the dog. Note that the aspect also changes here.

2. It would be important to note that given comments are usually not contrastive; they simply remind us that what is happening is happening to the person already introduced who is not in the focus of attention at the moment (see Seliverstova 1984; 454). This view on given comments also shows that we distinguish between focus and comment, i.e. there can be comments which are not placed in a paradigmatically or syntagmatically contrastive position (secondary characterization according to Seliverstova). 


\section{BIBLIOGRAPHY}

BENES̆, E. (1968): “On Two Aspects of FSP," Travaux linguistiques de Prague 3, pp. 267-274.

BÍLÍ, M. (1981): Intrasentential Pronomilization and FSP, Lund: Lund University Press.

BOLINGER, D.L. (1975): Meaning and Form, London \& New York: Longman.

CARMICHAEL, J. (transl.) (1960): Anna Karenina by Tolstoy, New York: Bantam Books.

DOLE, N.H. (transl.) (1886): Anna Kerenina by Count Lyof N. Tolstoy, New York: Crowell.

EDMONDS, R. (transI.) (1962): L.N. Tolstoy Anna Karenin, Harmondsworth: Penguin Books.

FIRBAS, J. (1964): "On Defining the Theme in Functional Sentence Analysis," Travaux linguistiques de Praque 1, pp. 267-280.

GARNETT, C. (transl.) (1917): Anna Karenin by Leo Tolstoy, New York: P.F. Collier \& Son Company.

GRZEGOREK, M. (1984): Thematization in English and Polish. A Siudy in Word Order, Poznan: Wyd-wo nauk.

HALLIDAY, M.A.K. (1967): "Notes on Transitivity and Theme in English," Journal of Linguistics 3, 1-2: pp. 37-91, 199-244.

JACKENDOFF, R. (1972): Semantic Interpretation in Generative Grammar, London: MIT Press.

MATHESIUS, V. (1967): "O tak nazyvaemom aktualnom tchlenenii predlozsenija," Prazsky Lingvistitseski Kruzsok, Ed. Kondrashov N.A., Moscow: Progress, pp. 239-245.

MAUDE, Louise and Aylmer (transl.) (1933): Anna Karenina by Leo Tolstoy, London: Humphrey Milford.

NIKOLAEVA, T.M. (1982): Semantika Aktsentnogo Vydelenija, Moscow: Nauka.

NOONAN, M. (1976): "On Subjects and Topics," Proceedings of the Third Annual Meeting of Berkeley Linguistic Society, Berkeley, California.

PROZOROVA, L.A. (1989): Osobennosti Postrojenija Kommunikativnoj Perspektivy v Hudozsestvennom Tekste (The Peculiarities of FSP Organization in Fiction), unpublished doctoral dissertation, Moscow.

PROZOROVA, L.A. (1990): “Are 'Rhematic' Subjects in English Rhematic Indeed?", Kalbotyra (autumn), Vilnius.

PROZOROVA, L.A., O.N. SELIVERSTOVA (1990): "Communicative Sentence Perspective and Style in Russian and English," Soviet Contributions to Some Linguistic Issues, Ed. Vassilevich A.P., Moscow: Nauka.

SELIVERSTOVA, O.N. (1984): "K Voprosu o Kommunikativnoj Strukture Predlozsenija" (To the Problem of the Communicative Structure of Sentence), Izvestija Akademii Nauk SSSR, Serija Literatury i jazyka, 43:5, pp. $443-456$.

SELIVERSTOVA, O.N., L.A. PROZOROVA (1990): "Kommunikativnaja Struktura Predlozsenija" (Communicative Sentence Structure), Teorija Funktsionalnoj Grammatiki, Ed. Bondarko A.V., Leningrad: Nauka, part 2.

SPERBER, D. and D. WILSON (1986): Relevance. Communication and Cognition, Oxford: Basil Blackwell.

SZWEDEK, A. (1989): "What is Topic? A Contrastivist's View," New Insight into Contrastive Linguistics, John Benjamin's Publ., pp. 499-506.

TOLSTOY, L.N. (1960): Anna Karenina, Petrozavodsk: Gosudarstvennoe izdatel'stvo Karelskoi ASSR.

TOWNSEND, R. (transl.) (1960): Leo Tolstoy. Anna Karenin, London: J.M. Dent \& Sons Ltd.

WEIL, H. (1869): De l'ordre des mots dans les langues anciennes comparées aux langues modernes. Questions de grammaire générale, Paris, Frank A.

WETTLIN, M. (transl.) (1982): Lev Tolstoy. Anna Karenina. Moscow: Progress Publishers. 